\title{
Numerical Classification of Rhodococcus (Formerly Gordona) Organisms Recently Isolated from Sputa of Patients: Description of Rhodococcus sputi Tsukamura sp. nov.
}

\author{
MICHIO TSUKAMURA \\ The National Chubu Hospital, Obu, Aichi, Japan 474
}

\begin{abstract}
A total of 116 strains of Rhodococcus (formerly Gordona) recently isolated from sputa of patients with pulmonary disease were submitted to numerical classification together with 61 reference strains belonging to the genera Rhodococcus, Nocardia, and Mycobacterium. The numerical classification was carried out by two methods, one using 109 characters and another using 98 characters. Almost similar results were obtained by these two methods, and the following clusters were distinguished: (i) Rhodococcus bronchialis (synonym: Gordona bronchialis); (ii) $R$. sputi sp. nov.; (iii) $R$. rubropertinctus (synonym: G. rubropertincta); (iv) R. rhodochrous (synonym: G. rhodochroa); (v) R. aurantiacus (synonym: G. aurantiaca); (vi) R. lentifragmentus (synonym: G. lentifragmenta); (vii) Nocardia rubra strains received from M. Ridell; (viii) N. asteroides; (ix) $N$. farcinica; (x) Mycobacterium fortuitum. Clusters i to vii were combined into one large cluster, which was considered as the genus Rhodococcus (synonym: Gordona). In addition, two (method I) or four (method II) new clusters could be observed among the cluster Rhodococcus. Thus, it was considered that the Rhodococcus organisms form a genus that contains a number of species. G. terrae and $G$. rosea were incorporated into the cluster of $R$. rubropertinctus ( $G$. rubropertincta), and were considered to be reduced to varieties of the species $R$. rubropertinctus. The largest one of the new clusters was named Rhodococcus sputi sp. nov. Tsukamura. Its definition is presented in this study. A proposal of changing the generic name from Gordona to Rhodococcus was made.
\end{abstract}

The so-called "rhodochrous" organisms were described by Gordon and Mihm (8), who differentiated some strains received as nocardiae from others and named Mycobacterium rhodochrous. Later Gordon (7) regarded this organism as an intermediate between Mycobacterium and $\mathrm{No}$ cardia. Tsukamura (14) isolated a number of slightly acid-fast organisms from sputa of patients and soils, and stated that they form a genus, Gordona. The genus was considered to occupy an adjacent taxonomic position to the genus Nocardia. M. rhodochrous ATCC 13808, which previously had been named $R$. rhodochrous, was included in this new genus. Thereafter, other strains received as $M$. rhodochrous, too, were included in this genus (15). The majority of the strains formed a species, G. rhodochroa, and a few other strains formed a species, $G$. rubropertincta, together with strains of $G$. rubra, a species previously described. $G$. rubra was renamed $G$. rubropertincta to conform to the rules of nomenclature. At that time, the following species were described: $G$. bronchialis (14); $G$. rubropertincta (synonym $G$. rubra) (15); G. terrae (14); G. rosea (15); G. rhodochroa (15); G. aurantiaca (19); G. lentifragmenta (20). Independently of these studies, Goodfellow and his associates $(4,5)$ reported that $M$. rhodochrous was differentiated from nocardiae and from rapidly growing mycobacteria. The rhodochrous taxon was considered to be distinguished from the genera Mycobacterium and Nocardia and to form a genus (6).

More recently, a number of strains considered to belong to the genus Gordona were isolated from sputa of patients with pulmonary disease. In an attempt to define the genus Gordona more accurately, a numerical classification using the recent isolates was carried out in the present study.

An appropriate name for the genus Gordona was considered to be Rhodococcus Zopf, as the type strain of $R$. rhodochrous Zopf (21) was contained in the genus (16). However, the generic name Gordona was tentatively used in the following studies, as the genus Gordona was the first name used for bringing this taxon up to its present form. Recently a similar proposal was made by Bousfield and Goodfellow (2), and, therefore, the generic name Gordona has been 
changed to Rhodococcus in the present study.

\section{MATERIALS AND METHODS}

A total of 177 strains of Rhodococcus (formerly Gordona), Nocardia, and Mycobacterium were studied. Of these, 61 strains shown in Table 1 were used as reference strains, and the remaining 116 strains were isolated recently in this laboratory from sputa of patients with cavitary pulmonary tuberculosis or bronchiectasis. All 116 strains were considered to belong to the taxon Rhodococcus, as they showed common characters of the Rhodococcus that are shown below.

Numerical classification was carried out by two methods: the first (method I) used a total of 109 characters (Table 2) and the second (method II) used a total of 98 characters. In method II, the following were omitted from the set of characters of method I: acid from galactose, arabinose, xylose, rhamnose, trehalose, inositol, mannitol, and sorbitol; L-methionine as the $\mathrm{N}$ source; isonicotinamide as the $\mathrm{N}$ source; succinamide as the $\mathrm{N}$ source. Eight of these 11 characters were omitted because acid formation from carbohydrates may have a close correlation with the utilization of these carbohydrates as $\mathrm{C}$ source.

References to the tests were given in two previous papers $(12,18)$.

Numerical classification was carried out as follows. The results were recorded as + or - , and the matching coefficient (M-value) was calculated by the following equation: $\mathrm{M}(\%)=\left[n_{s} /\left(n_{s}+n_{d}\right)\right] \times 100 \%$, where $n_{s}$ is the number of characters that give the same results between two strains, and $n_{d}$ is the number of characters that give different results. The computer used was an IBM-S370 model 135 located in the Nagoya Factory of the Sumitomo Machinery Co., Obu, Aichi, Japan. The program (G90002) is written in English (CŌBŌL). The complete sets of data have been deposited with the WFCC World Data Center for Microorganisms, Department of Microbiology, University of Queensland, Brisbane, Australia.

The results of the numerical classification are shown as dendrograms, which were prepared by the singlelinkage method (11).

Four characters showed positive matches for all strains: gram-positiveness; growth at $37^{\circ} \mathrm{C}$; growth on the TCH medium; growth on salicylate-Ogawa egg medium. Four characters showed negative matches for all strains: growth at $52^{\circ} \mathrm{C}$; salicylamidase; succinamidase; utilization of benzamide as simultaneous $\mathbf{N}$ and $\mathrm{C}$ sources. Accordingly, the number of characters effective for differentiating the test strains were 101 and 90 in methods I and II, respectively.

\section{RESULTS}

Method I. The dendrogram (Fig. 1 to 3 ) showed the following 12 clusters at the $93 \%$ level: (A) R. bronchialis (formerly G. bronchialis); (B) $R$. sputi sp. nov.; (C) R. rubropertinctus (formerly $G$. rubropertincta), $R$. terrae (formerly G. terrae); and $R$. roseus (formerly $G$. rosea); (D) $R$. aurantiacus (formerly G. aurantiaca); (E) a new taxon; (F) $R$. rhodochrous (formerly G. rhodochroa); (G) N. rubra (Ridell);
(H) $R$. lentifragmentus (formerly G. lentifragmenta); (I) N. asteroides; (J) a new taxon; (K) $N$. farcinica; (L) M. fortuitum. Clusters B, E, and $\mathrm{J}$ were composed of recently isolated $R h o-$ dococcus organisms and did not belong to any known species.

Method II. The dendrogram (Fig. 4 to 6) showed 14 clusters at the $92 \%$ level (C and $\mathrm{F}$ at the $94 \%$ level). Of these, 12 were the same as shown in method I, and the other two clusters ( $M$ and $\mathrm{N}$ ) appeared to be new. Hence, the clusters not encountered previously were $B, E$, $J, M$, and $N$. The number of strains forming the clusters was similar in both methods, except for the cluster B, which was composed of 25 strains in method I and 16 strains in method II. The unnamed clusters were considered to belong to new species. Only cluster B was named $R$. sputi sp. nov. Tsukamura. The range of the taxon Rhodococcus was considered to be a large cluster delineated by the 88 or $89 \%$ levels in methods I and II, respectively.

Characters useful for distinguishing the clusters are shown in Table 3.

The common characters of the Rhodococcus (formerly Gordona) organisms are as follows: gram positive; usually slightly acid fast; mycelium not formed; occur as short rods or coccoids; form rough, pinkish, reddish, brownish, or orange-pigmented colonies on egg media; pigmentation of colonies enhanced by light exposure; grow after 3 days on egg media and Sauton agar; grow at 28 and $37^{\circ} \mathrm{C}$ but do not grow at $45^{\circ} \mathrm{C}$; grow on Ogawa egg medium containing $0.2 \%$ sodium $p$-aminosalicylate (PAS); grow on Ogawa egg medium containing $0.5 \mathrm{mg}$ of sodium salicylate per ml; grow on Ogawa egg medium containing $0.25 \mathrm{mg}$ of $\mathrm{NH}_{2} \mathrm{OH} \cdot \mathrm{HCl}$ per ml; grow on Sauton agar containing $0.2 \%$ picric acid; grow on Sauton agar containing $0.1 \% \mathrm{NaNO}_{2}$; PAS and salicylate not degraded; arylsulfatase negative; utilize L-glutamate but do not utilize benzamide and trimethylene diamine as simultaneous $\mathbf{N}$ and $\mathbf{C}$ sources; utilize glycerol, glucose, mannose, fructose, sucrose, $n$-propanol, acetate, succinate, malate, and pyruvate as sole $C$ sources in the presence of ammoniacal nitrogen; do not utilize arabinose and xylose as sole $\mathrm{C}$ sources and do not form acid from these pentoses; utilize $\mathrm{L}$-serine, L-methionine, and pyrazinamide as sole $\mathrm{N}$ sources in the presence of glycerol carbon; $\beta$ galactoside negative.

Description of Rhodococcus sputi sp. nov. Tsukamura. Characters useful for distinguishing this species from others are as follows. This species without exception does not grow on Sauton agar containing $0.1 \% \mathrm{NaNO}_{2}$; does not grow on Sauton agar containing $0.1 \%$ sodium salicylate; grows on Ogawa egg medium containing 0.5 
TABLE 1. List of strains used in this study ${ }^{a}$

\begin{tabular}{|c|c|c|c|c|c|}
\hline \multirow{2}{*}{ Cluster } & \multirow{2}{*}{$\begin{array}{l}\text { Laboratory } \\
\text { no. }\end{array}$} & \multicolumn{2}{|l|}{ Received as: } & \multirow{2}{*}{ Source $^{b}$} & \multirow{2}{*}{ Habitat } \\
\hline & & Name & Strain & & \\
\hline \multirow[t]{6}{*}{ A } & 3410 & Gordona bronchialis & ATCC 25592 & 1 & Human sputum \\
\hline & 3411 & G. bronchialis & 50004 & 2 & Human sputum \\
\hline & 3413 & G. bronchialis & 50006 & 2 & Human sputum \\
\hline & 3885 & G. bronchialis & 50013 & 2 & Human sputum \\
\hline & 3924 & G. bronchialis & 50017 & 2 & Human sputum \\
\hline & 3926 & G. bronchialis & 50019 & 2 & Human sputum \\
\hline \multirow[t]{7}{*}{$\mathrm{C}$} & 3602 & G. rubropertincta & 60002 & 2 & Soil \\
\hline & 3605 & G. rubropertincta & ATCC 25593 & 1 & Soil \\
\hline & 3612 & G. terrae & ATCC 25594 & 1 & Soil \\
\hline & 5655 & Mycobacterium rhodochrous ${ }^{c}$ & ATCC 271 & 1 & $?$ \\
\hline & 5658 & M. rhodochrous ${ }^{c}$ & ATCC 4004 & 1 & ? \\
\hline & 5665 & M. rhodochrous & ATCC 14343 & 1 & ? \\
\hline & 5674 & M. rhodochrous & ATCC 19067 & 1 & ? \\
\hline D & 3462 & G. aurantiaca & ATCC 25938 & 1 & Human sputum \\
\hline \multirow[t]{8}{*}{$\mathrm{F}$} & 5657 & M. rhodochrous & ATCC 4001 & 1 & ? \\
\hline & 5659 & M. rhodochrous & ATCC 4276 & 1 & ? \\
\hline & 5660 & M. rhodochrous & ATCC 4273 & 1 & ? \\
\hline & 5663 & M. rhodochrous & ATCC 13808 & 1 & ? \\
\hline & 5664 & M. rhodochrous & ATCC 14341 & 1 & ? \\
\hline & 5666 & M. rhodochrous & ATCC 14347 & 1 & ? \\
\hline & 5667 & M. rhodochrous & ATCC 14348 & 1 & ? \\
\hline & 5668 & M. rhodochrous & ATCC 14349 & 1 & $?$ \\
\hline \multirow[t]{5}{*}{ G } & 7566 & Nocardia rubra & $\mathrm{N} 20$ & 3 & ? \\
\hline & 7567 & N. rubra & N21 & 3 & ? \\
\hline & 7568 & N. rubra & N24 & 3 & ? \\
\hline & 7570 & N. rubra & $\mathrm{N} 26$ & 3 & ? \\
\hline & 7572 & N. rubra & N50 & 3 & $?$ \\
\hline \multirow[t]{4}{*}{$\mathrm{H}$} & 23002 & N. rubra ${ }^{d}$ & M-1 & 4 & ? \\
\hline & 23021 & N. minima $a^{d}$ & M-103 & 4 & $?$ \\
\hline & 23022 & N. coeliaca ${ }^{d}$ & M-122 & 4 & ? \\
\hline & 23024 & N. lutea $a^{d}$ & M-192 & 4 & $?$ \\
\hline \multirow[t]{6}{*}{ I } & 23056 & N. asteroides & M-155 & 4 & ? \\
\hline & 23057 & N. asteroides & M-156 & 4 & $?$ \\
\hline & 23088 & $N$. asteroides & M-206 & 4 & $?$ \\
\hline & 23095 & N. asteroides & R 443 (1) & 5 & $?$ \\
\hline & 23097 & N. asteroides & R 553 & 5 & ? \\
\hline & 23103 & N. asteroides & ATCC $9970^{\circ}$ & 1 & ? \\
\hline \multirow[t]{10}{*}{$\mathbf{K}$} & 7547 & N. farcinica $f^{\prime}$ & VAC 300 & 6 & ? \\
\hline & 7548 & N. farcinica $f^{f}$ & VAC 324 & 6 & ? \\
\hline & 7549 & N. farcinicaf & VAC 330 & 6 & ? \\
\hline & 7550 & N. farcinica ${ }^{f}$ & VAC 333 & 6 & $?$ \\
\hline & 7551 & N. farcinica $f^{f}$ & VAC 462 & 6 & $?$ \\
\hline & 7815 & N. farcinica ${ }^{f}$ & 3318/AL & 7 & ? \\
\hline & 23018 & N. globerula & M-75 & 4 & ? \\
\hline & 23102 & N. farcinica & ATCC $3318^{e}$ & 1 & $?$ \\
\hline & 18001 & Mycobacterium fortuitum. & ATCC 19709 & 1 & Soil \\
\hline & 18009 & M. fortuitum & NCTC 8697 & 8 & $?$ \\
\hline \multirow[t]{5}{*}{$\mathrm{L}$} & 18112 & M. fortuitum & ATCC 6841 & 1 & Human \\
\hline & 42001 & M. minetti & ATCC 19542 & 1 & $?$ \\
\hline & 5654 & M. rhodochrous & ATCC 184 & 1 & ? \\
\hline & 5656 & M. rhodochrous & ATCC 999 & 1 & $?$ \\
\hline & 5669 & M. rhodochrous & ATCC 14350 & 1 & ? \\
\hline
\end{tabular}


TABLE 1-continued

\begin{tabular}{|c|c|c|c|c|c|}
\hline \multirow{2}{*}{ Cluster } & \multirow{2}{*}{$\begin{array}{l}\text { Laboratory } \\
\text { no. }\end{array}$} & \multicolumn{2}{|c|}{ Received as: } & \multirow{2}{*}{ Source $^{b}$} & \multirow{2}{*}{ Habitat } \\
\hline & & Name & Strain & & \\
\hline \multirow{9}{*}{$-g$} & 6038 & Nocardia sp. & & 2 & Human sputum \\
\hline & 6618 & Jensenia canicruria & KCC A-0132 & 9 & $?$ \\
\hline & 7565 & N. rubra & N69 & 3 & $?$ \\
\hline & 7571 & N. rubra & N27 & 3 & $?$ \\
\hline & 7573 & N. rubra & N51 & 3 & $?$ \\
\hline & 7586 & $N$. sp. & & 2 & Human sputum \\
\hline & 7808 & R. coprophilus & CUB 887 & 10 & ? \\
\hline & 23023 & N. rubropertincta & M-191 & 4 & $?$ \\
\hline & 23030 & N. polychromogenes & M-6 & 4 & $?$ \\
\hline
\end{tabular}

${ }^{a}$ The other 116 strains not listed in this table were isolated from the sputum of patients by the present author and were considered to belong to Gordona sp. These strains appear in dendrograms showing our laboratory number.

${ }^{b}$ (1) American Type Culture Collection (ATCC), Rockville, MD 20852; (2) M. Tsukamura, National Chubu Hospital, Obu, Aichi 474, Japan; (3) M. Ridell, Institute of Medical Microbiology, University of Göteborg, Sweden; (4) N. M. McClung, University of South Florida, Tampa, FL 33620 (received through I. Uesaka, Kyoto University, Kyoto, Japan); (5) R. E. Gordon, Institute of Microbiology, Rutgers, State University of New Jersey, New Brunswick, NJ 08903; (6) S. G. Bradley, Department of Microbiology, Virginia Commonwealth University, Richmond, VA 23219; (7) H. A. Lechevalier, Institute of Microbiology, Rutgers, State University of New Jersey, New Brunswick, NJ 08903; (8) National Collection of Type Cultures (NCTC), Central Public Health Laboratory, London NW9 5HT, England (received through K. Takeya, Department of Microbiology, Kyushu University, Fukuoka, Japan); (9) A. Seiya, Kaken Chemical Industries, Tokyo, Japan (the strain is equivalent to ATCC 11048; NCTC 8036); (10) T. Cross, Postgraduate School of Studies in Biological Sciences, University of Bradford, Bradford BD7 1DP, England.

${ }^{c}$ These strains were identified as $G$. rosea by Tsukamura (14).

${ }^{d}$ These strains were identified by Tsukamura et al. (19) as G. lentifragmenta.

e These two ATCC strains were not received directly from the ATCC but from R. E. Gordon, Institute of Microbiology, Rutgers, State University of New Jersey, New Brunswick, NJ 08903.

' These strains were identified by the present author as $N$. farcinica according to the definition previously described (12).

$g$ These strains did not form any cluster.

mg of $p$-nitrobenzoic acid per $\mathrm{ml}, 25 \mu \mathrm{g}$ of rifampin per $\mathrm{ml}$, and/or $5 \mu \mathrm{g}$ of ethambutol per $\mathrm{ml}$; Tween not hydrolyzed after 7 days but hydrolyzed after 14 days; catalase positive; $\alpha$ - and $\beta$ esterases negative; acid phosphatase positive; nitrate reduced to nitrite after $24 \mathrm{~h}$; acetamidase, urease, nicotinamidase, pyrazinamidase, and allantoinase are produced, but benzamidase, isonicotinamidase, salicylamidase, succinamidase are not produced; acetamide and monoethanolamine utilized and L-serine, glucosamine hydrochloride, benzamide, and trimethylene diamine not utilized as simultaneous $\mathbf{N}$ and $\mathrm{C}$ sources; ethanol, $n$-butanol, isobutanol, citrate, and fumarate are utilized, and benzoate, malonate, propylene glycol, 1,3-, 1,4-, and 2,3-butylene glycols not utilized as sole C sources; acid formed from glucose, mannose, trehalose, mannitol, and sorbitol, but acid not formed from galactose, arabinose, xylose, rhamnose, and inositol; acetamide, urea, nicotinamide, succinamide, and nitrate utilized, but benzamide, isonicotinamide, and nitrite not utilized as sole $\mathrm{N}$ sources in the presence of glycerol carbon.

The type strain is ATCC 29627 (no. 3884 Tsukamura), which is deposited in the American Type Culture Collection, Rockville, Md.

\section{DISCUSSION}

Previously, G. rubropertincta, G. terrae, and $G$. rosea (now $R$. rubropertinctus, $R$. terrae, and $\boldsymbol{R}$. roseus, respectively) were regarded as different species, although they together were part of a large common cluster $(15,16)$. In contrast to this, the results of the present study showed that these three taxa can be combined into one species, namely $R$. rubropertinctus, and that $R$. terrae and $R$. roseus should be reduced to varieties of the species $R$. rubropertinctus. This lumping occurred probably because three enzyme tests, $\beta$-galactosidase, catalase, and acid phosphatase tests, which were not used in previous studies, were used in the present study and gave the same reactions for these taxa.

The type strain of Jensenia canicruria (no. 6618) was included to the Rhodococcus cluster at the $88 \%$ (method I) or $89 \%$ (method II) level.

Strains received as $N$. rubra from $M$. Ridell belonged to a cluster different from that of $R$. lentifragmentus (formerly $G$. lentifragmenta) which had been named $N$. rubra $(13,20)$. Ridell's $N$. rubra strains also were considered to belong to a species of the genus Rhodococcus. Ridell (10) reported previously that these strains and $M$. rhodochrous strains revealed a close serolog- 
TABLE 2. Characters tested ${ }^{a}$
1. Gram positiveness
2. Acid fastness (complete)
3. Acid fastness (partial or slight)
4. Permanent mycelium
5. Fragmenting mycelium
6. Rod shape
7. Cord formation
8. Rough colonies
9. Colony pigmentation (in dark)
10. Photochromogenicity
11. Growth after 3 days
12. Growth at $28^{\circ} \mathrm{C}$
13. Growth at $37^{\circ} \mathrm{C}$
14. Growth at $45^{\circ} \mathrm{C}$
15. Growth at $52^{\circ} \mathrm{C}$
16. Growth on $0.2 \%$-aminosalicylic acid
17. $p$-Aminosalicylic acid degradation
18. Growth on $\mathrm{NH}_{2} \mathrm{OH} \cdot \mathrm{HCl}(0.125 \mathrm{mg} / \mathrm{ml})$
19. Growth on $\mathrm{NH}_{2} \mathrm{OH} \cdot \mathrm{HCl}(0.25 \mathrm{mg} / \mathrm{ml})$
20. Growth on $\mathrm{NH}_{2} \mathrm{OH} \cdot \mathrm{HCl}(0.5 \mathrm{mg} / \mathrm{ml})$
21. Growth on Sauton agar
22 . Growth on salicylate agar $(0.1 \%)$
23. Salicylate degradation
24. $0.1 \%$ Picric acid-Sauton agar
25. $0.2 \%$ Picric acid-Sauton agar
26. Three-day arylsulfatase
27. Two-week arylsulfatase
28. $\mathrm{TCH}$ medium $(10 \mu \mathrm{g} / \mathrm{ml})$
29. Salicylate $(0.5 \mathrm{mg} / \mathrm{ml})$-Ogawa medium
30. Ethambutol $(5 \mu \mathrm{g} / \mathrm{ml})$-Ogawa medium
31. $0.1 \% \mathrm{NaNO}_{2}$-Sauton agar
32. $0.2 \% \mathrm{NaNO}_{2}$-Sauton agar
33. $1 \%$ Tween-Sauton agar
34. $\mathrm{PNB}$ medium $(0.5 \mathrm{mg} / \mathrm{ml})$
35. Rifampin $(25 \mu \mathrm{g} / \mathrm{ml})$-Ogawa medium
36. Tween hydrolysis ( 7 days)
37. Tween hydrolysis (14 days)
38. Catalase (foam height $>45 \mathrm{~mm}$ )
39. $\alpha$-Esterase
40. $\beta$-Esterase
41. $\beta$-Galactosidase
42. Acid phosphatase
43. Nitrate reduction $(6 \mathrm{~h})$
44. Nitrate reduction (24 hours)
45. Acetamidase
46. Benzamidase
47. Urease
48. Isonicotinamidase
49. Nicotinamidase
50. Pyrazinamidase
51. Salicylamidase
52. Allantoinase
53. Succinamidase
54. L-Glutamate as $\mathrm{N}$ and $\mathrm{C}$ sources
55. L-Serine as $\mathrm{N}$ and $\mathrm{C}$ sources

${ }^{a}$ Method I includes all above 109 characters. Method II includes 98 characters, but excludes 82 to 89,100 , 106 , and 107.

ical relationship. Bradley (3) also stated that $N$. rubra should be placed in the taxon rhodochrous. Their results agree with the results of the present study. On the other hand, strain 23030 received as $N$. polychromogenes M-6 (N.
57. Acetamide as $\mathrm{N}$ and $\mathrm{C}$ sources

58. Benzamide as $\mathrm{N}$ and $\mathrm{C}$ sources

59. Monoethanolamine as $\mathrm{N}$ and $\mathrm{C}$ sources

60. Trimethylene diamine as $\mathrm{N}$ and $\mathrm{C}$ sources

61. Glucose as $\mathrm{C}$ source

62. $n$-Propanol as $\mathrm{C}$ source

63. $n$-Butanol as $\mathrm{C}$ source

64. Isobutanol as $\mathrm{C}$ source

65. Acetate as $\mathrm{C}$ source

66. Citrate as $\mathrm{C}$ source

67. Succinate as $\mathrm{C}$ source

68. Malate as $\mathrm{C}$ source

69. Pyruvate as $\mathrm{C}$ source

70. Benzoate as C source

71. Malonate as $\mathrm{C}$ source

72. Fumarate as $\mathrm{C}$ source

73. Fructose as $\mathrm{C}$ source

74. Sucrose as $\mathrm{C}$ source

75. Ethanol as $\mathrm{C}$ source

76. Propylene glycol as $\mathrm{C}$ source

77. 1,3-Butylene glycol as $\mathbf{C}$ source

78. 1,4-Butylene glycol as $\mathrm{C}$ source

79. 2,3-Butylene glycol as $\mathrm{C}$ source

80. Acid from glucose

81. Acid from mannose

82. Acid from galactose

83. Acid from arabinose

84. Acid from xylose

85. Acid from rhamnose

86. Acid from trehalose

87. Acid from inositol

88. Acid from mannitol

89. Acid from sorbitol

90. Mannose as $\mathrm{C}$ source

91. Galactose as $\mathrm{C}$ source

92. Arabinose as $\mathrm{C}$ source

93. Xylose as C source

94. Rhamnose as $\mathrm{C}$ source

95. Trehalose as $\mathrm{C}$ source

96. Inositol as $\mathrm{C}$ source

97. Mannitol as C source

98. Sorbitol as C source

99. L-Serine as $\mathbf{N}$ source

101. L-Methionine as $\mathbf{N}$ source

101. Acetamide as $\mathbf{N}$ source

102. Benzamide as $\mathbf{N}$ source

103. Urea as $\mathbf{N}$ source

104. Pyrazinamide as $\mathrm{N}$ source

105. Nicotinamide as $\mathrm{N}$ source

106. Isonicotinamide as $\mathbf{N}$ source

107. Succinamide as $\mathbf{N}$ source

108. Nitrate as $\mathbf{N}$ source

109. Nitrite as $\mathrm{N}$ source 


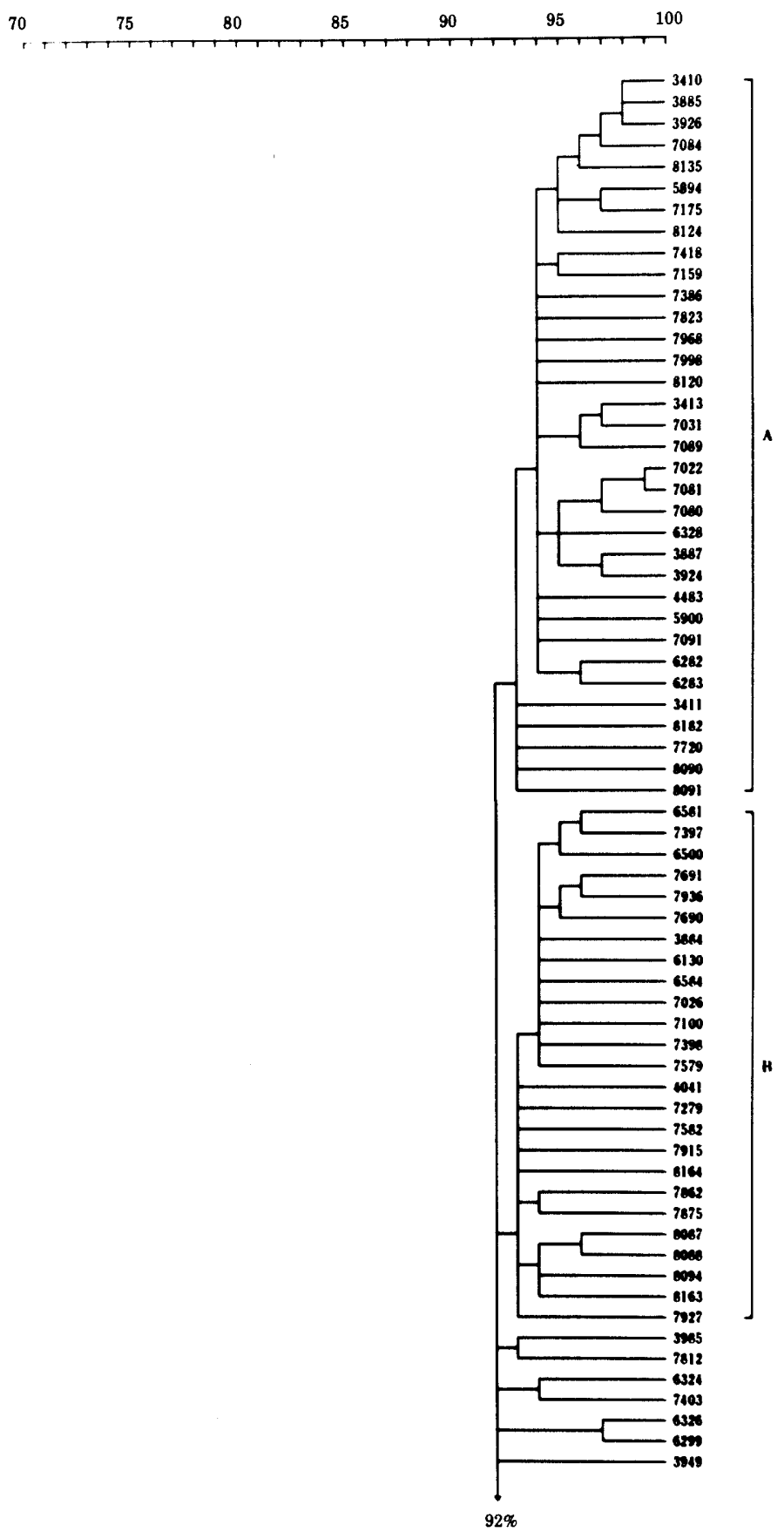

FIG. 1. Dendrogram (method I). (A) Rhodococcus bronchialis (formerly Gordona bronchialis); (B) R. sputi sp. nov.

of $R$. rubropertinctus and were distinguished from other strains that were received as $M$. rhodochrous but that belonged to another cluster, $R$. rhodochrous. The clusters of these two taxa could be distinguished by method I, whereby they belonged to the same cluster, although they could be seen as two subclusters by method II. The result of method II is similar to that of Goodfellow et al. (6), who could not distinguish them as separate taxa. 


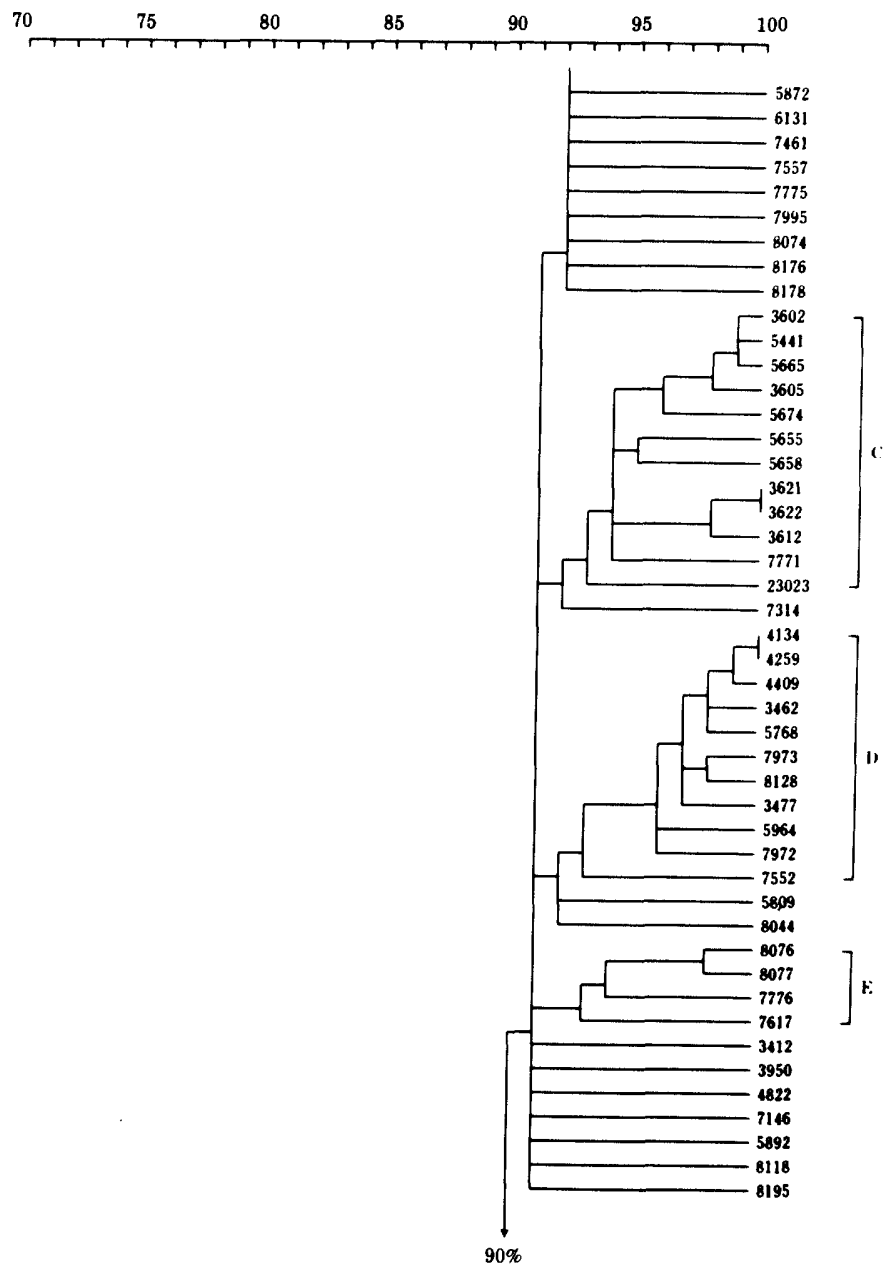

FIG. 2. Dendrogram (method I). (C) Rhodococcus rubropertinctus (formerly Gordona rubropertincta); (D) R. aurantiacus (formerly G. aurantiaca).

By method I, three hitherto unnamed clusters could be found, whereas by method II, five new clusters could be found. Except for these differences, two methods of the numerical classification gave similar clusters. Method I contains eight characters of acid formation from carbohydrates which probably have the same significance as the tests for the utilization of the same carbohydrates. Therefore, method II is regarded as more appropriate. However, both methods gave similar results as a whole. This means that the use of a large number of characters as used in the present study can weaken the influence of linked characters. Furthermore, it is noteworthy that method II, despite its fewer characters, has given more clusters. It is suggested that a greater number of characters is not always advantageous, and that inclusion of characters with similar significance renders obscure some clusters.
It should be emphasized that the characters for numerical classification have to be unrelated to each other.

Problem of nomenclature. In 1971, Tsukamura (14) proposed to create a genus Gordona for slightly acid-fast organisms isolated from sputa of patients and soils. At that time, he showed that the type strain of $R$. rhodochrous ATCC 13808 was contained in the genus, although it did not belong to any existing species. Soon thereafter, Goodfellow and his associates $(4,5)$ showed that the rhodochrous complex was differentiated from mycobacteria and nocardia. Tsukamura $(15,16)$ reported that a number of strains of the rhodochrous complex were included in the genus Gordona. He considered Rhodococcus to be an appropriate name for this genus (16). However, the name Gordona was used successively to avoid confusion in nomen- 


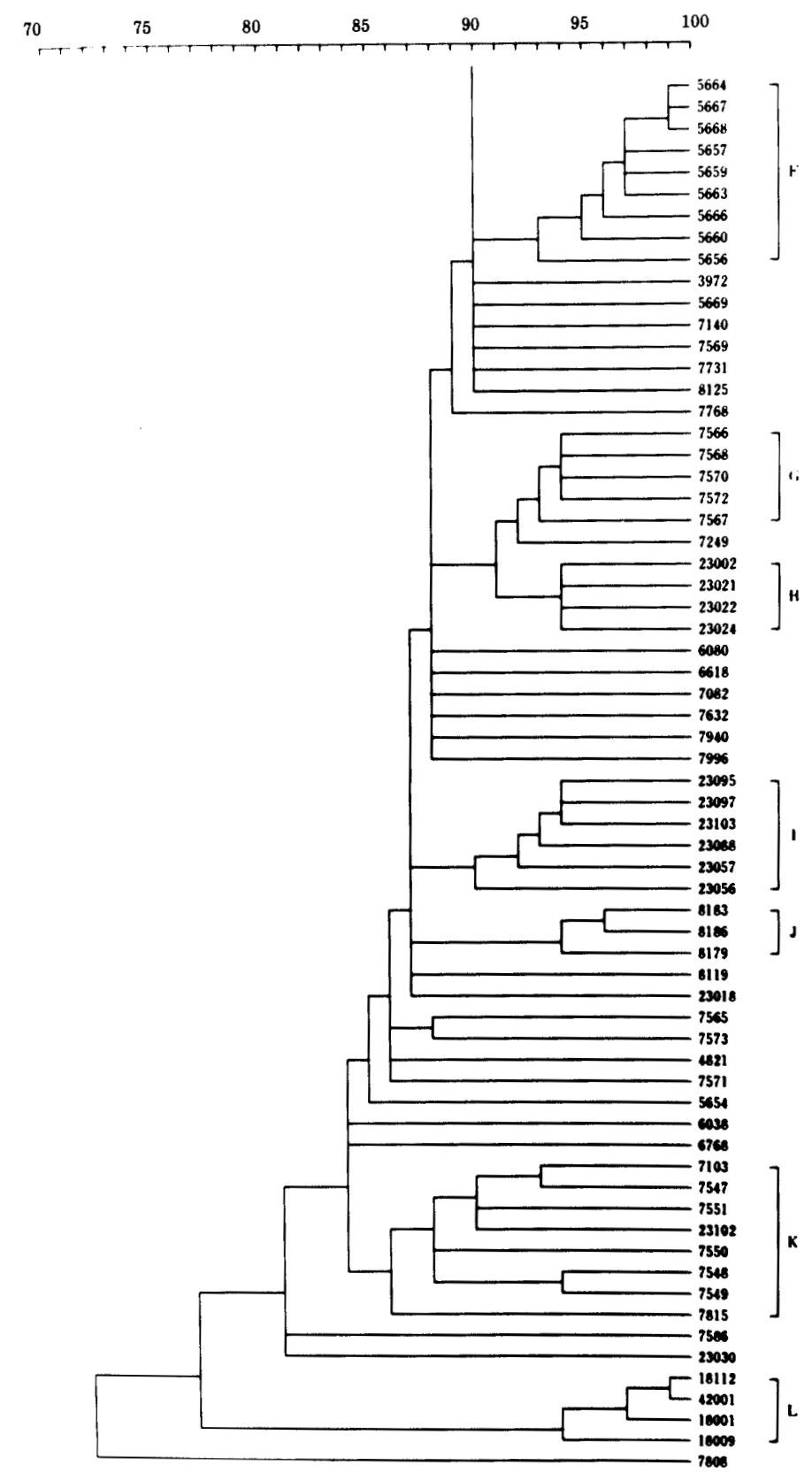

FIG. 3. Dendrogram (method I). (F) Rhodococcus rhodochrous (formerly Gordona rhodochroa); (G) Nocardia rubra (Ridell); (H) R. lentifragmentus (formerly G. lentifragmenta); (I) N. asteroides; (K) N. farcinica; (L) Mycobacterium fortuitum.

clature. A further study of the relationships among Mycobacterium, Gordona including rhodochrous organisms, and Nocardia showed that Gordona is a taxon comparable with the genera
Mycobacterium and Nocardia (17). The results of the present study also showed that the taxon is clearly separated from Nocardia. Recently, Bousfield and Goodfellow (2) stated that the 


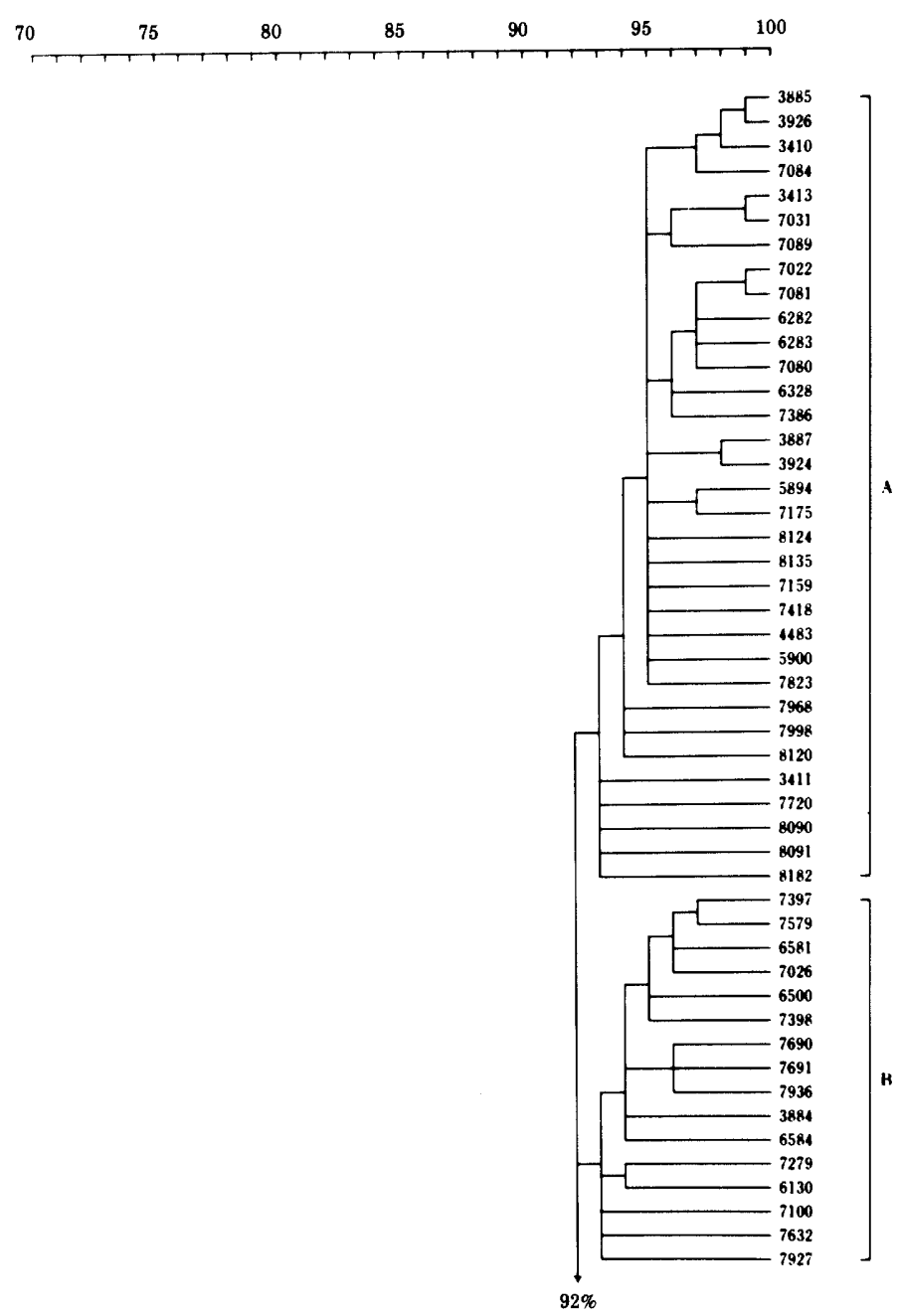

FIG. 4. Dendrogram (method II). (A) Rhodoccus broncialis (formerly Gordona bronchialis); (B) R. sputi sp. nov. 


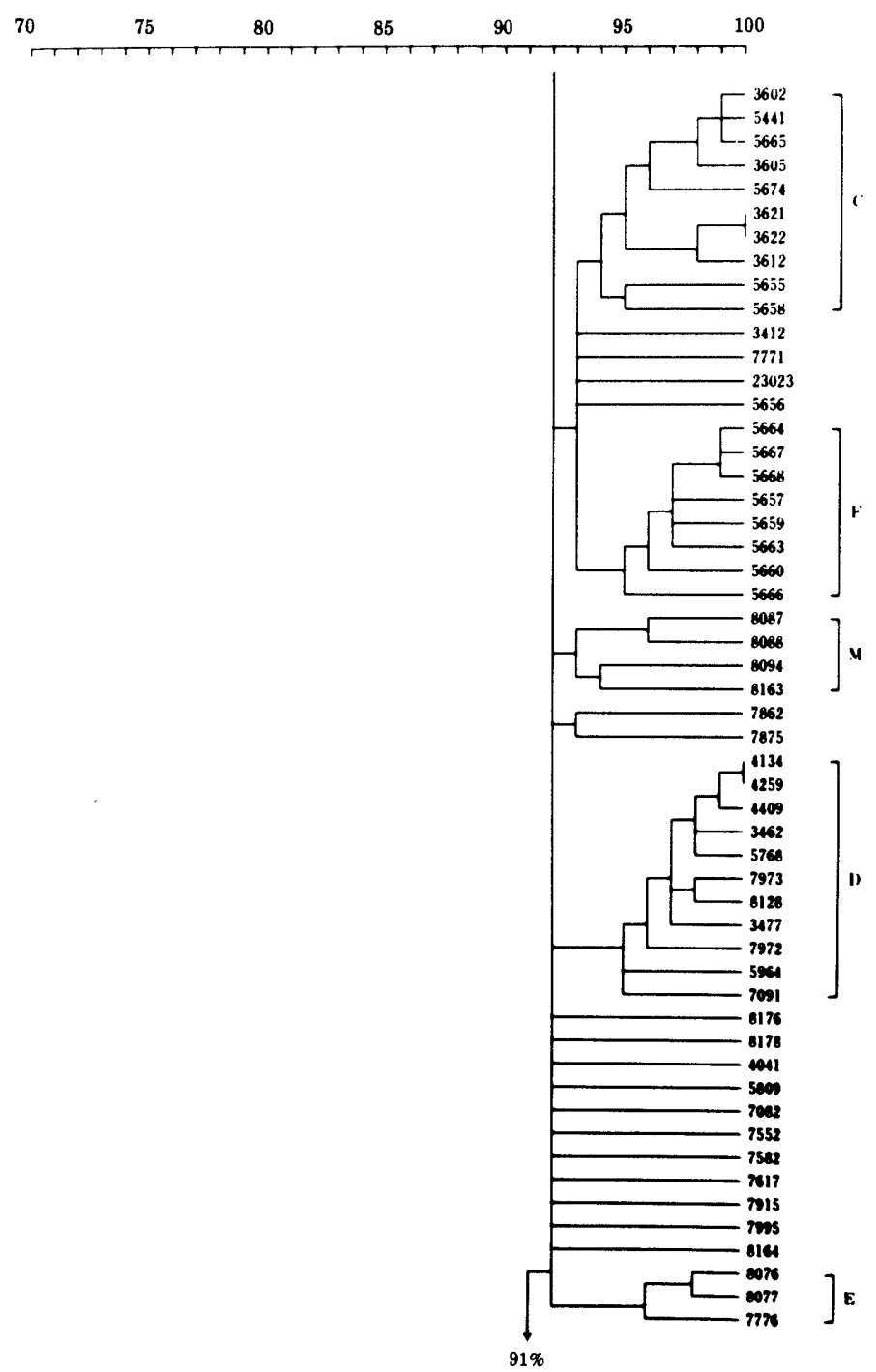

FIG. 5. Dendrogram (method II). (C) Rhodoccus rubropertinctus (formerly Gordona rubropertincta); (D) $R$. aurantiacus (formerly G. aurantiaca); (F) R. rhodochrous (formerly G. rhodochroa).

rhodochrous complex should be regarded as a genus and its generic name should be Rhodococcus. Their proposal agrees with a previous proposal of the present author (16). In consideration of these agreements, it is now the time to change the generic name form Grodona to Rhodococcus.

The relationship between the genus Gordona and the rhodochrous complex is troublesome. Alshamaony et al. (1) reported that the mycolic acids from the Gordona strains formed a group intermediate in size between nocardomycolic acids and mycolic acids sensu stricto, and they regarded Gordona as a different taxon from the taxa Mycobacterium, rhodochrous, and Nocardia. Mordarski et al. (9) reported that the values for deoxyribonucleic acid (DNA) relatedness between the taxon Gordona and the taxon rhodochrous were comparatively low. However, conclusions of Tsukamura $(14,17)$ and Alshamaony et al. (1) agree in that they regard Gordona as a taxon more closely related to Nocardia than to Mycobacterium. The findings of Alshamaony et al. (1) and Mordarski et al. (9) show that Gordona sensu stricta and the rhodochrous complex have some differences. If one regards, however, these differences as those within a genus, one would be able to regard 
VoL. 28,1978

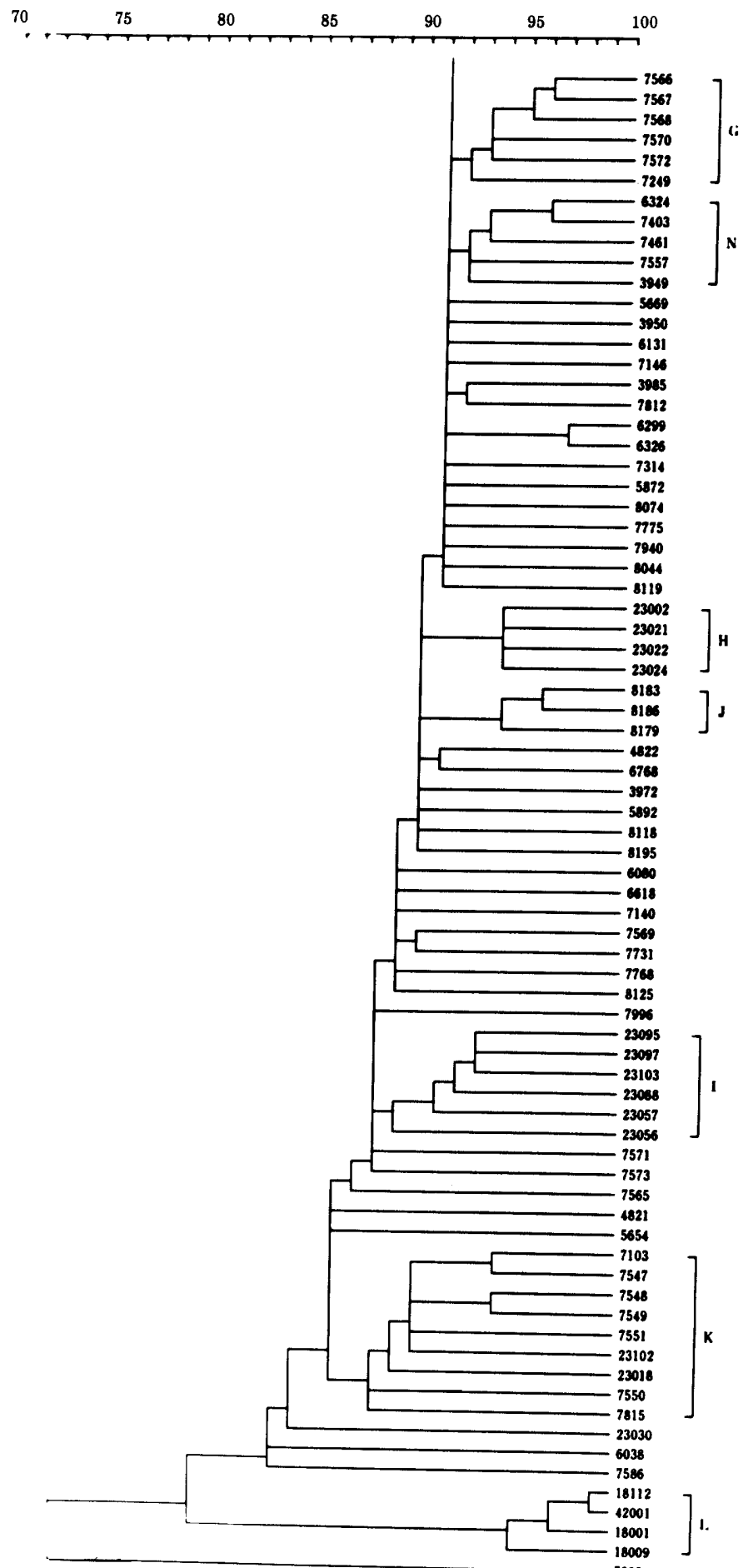

Fig. 6. Dendrogram (method II). (G) Nocardia rubra (Ridell); (H) Rhodococcus lentifragmentus (formerly Gordona lentifragmenta); (I) N. asteroides; (K) N. farcinica; (L) Mycobacterium fortuitum. 
TABLE 3. Characters useful for differentiating Gordona and Nocardia species studied in the present study

\begin{tabular}{|c|c|c|c|c|c|c|c|c|c|c|c|c|c|}
\hline \multirow{2}{*}{ Character } & \multicolumn{13}{|c|}{ Strains (\%) showing positive reaction } \\
\hline & $\mathrm{A}^{a}$ & B & $\mathbf{C}$ & D & $\mathbf{E}$ & F & G & $\mathbf{H}$ & I & $\mathrm{J}$ & $\mathrm{K}$ & $\mathbf{M}$ & $\mathbf{N}$ \\
\hline & $33^{b}$ & 16 & 10 & 11 & 3 & 8 & 5 & 4 & 6 & 3 & 9 & 4 & 5 \\
\hline $\begin{array}{l}\text { Partial or slight acid fast- } \\
\text { ness }\end{array}$ & 76 & 88 & 90 & 73 & 0 & 13 & 0 & 100 & 100 & 0 & 55 & 0 & 100 \\
\hline Fragmenting mycelium & 3 & 0 & 0 & 0 & 0 & 13 & 80 & 100 & 100 & 0 & 89 & 0 & 0 \\
\hline Growth at $45^{\circ} \mathrm{C}$ & 0 & $\mathbf{0}$ & 0 & 0 & 0 & 0 & 40 & 0 & 0 & 0 & 100 & 0 & 0 \\
\hline Growth on salicylate agar & 21 & 6 & 20 & 91 & 100 & 75 & 0 & 0 & 0 & 67 & 0 & 100 & 40 \\
\hline $\begin{array}{l}\text { Ethambutol-Ogawa me- } \\
\text { dium }\end{array}$ & 100 & 94 & 100 & 100 & 100 & 100 & 100 & 0 & 100 & 100 & 100 & 100 & 100 \\
\hline $0.1 \% \mathrm{NaNO}_{2}-$ Sauton agar & 48 & 6 & 100 & 91 & 100 & 100 & 100 & 100 & 83 & 67 & 33 & 0 & 0 \\
\hline PNB medium & 79 & 88 & 100 & 91 & 100 & 100 & 0 & 100 & 100 & 100 & 100 & 100 & 100 \\
\hline Rifampin-Ogawa medium & 58 & 100 & 100 & 100 & 100 & 100 & 100 & 0 & 100 & 100 & 100 & 100 & 100 \\
\hline $\begin{array}{l}\text { Tween hydrolyzed after } 14 \\
\text { days }\end{array}$ & 3 & 69 & 0 & 91 & 100 & 0 & 80 & 0 & 33 & 0 & 55 & 75 & 80 \\
\hline Catalase (semiquantitative) & 97 & 100 & 100 & 91 & 33 & 100 & 80 & 50 & 50 & 0 & 44 & 100 & 80 \\
\hline$\alpha$-Esterase & 0 & 38 & 30 & 0 & 0 & 0 & 0 & 0 & 83 & 0 & 0 & 50 & 100 \\
\hline$\beta$-Esterase & 97 & 13 & 90 & 45 & 0 & 100 & 20 & 0 & 83 & 0 & 67 & 0 & 60 \\
\hline$\beta$-Galactose & 3 & 0 & 0 & 91 & 0 & 0 & 0 & 0 & 100 & 0 & 100 & 0 & 0 \\
\hline Acid phosphatase & 94 & 88 & 0 & 9 & 100 & 0 & 0 & 0 & 17 & 100 & 22 & 25 & 100 \\
\hline Nitrate reduction (24 h) & 91 & 44 & 100 & 9 & 0 & 100 & 100 & 50 & 0 & 33 & 0 & 0 & 80 \\
\hline Acetamidase & 100 & 69 & 20 & 91 & 100 & 25 & 100 & 100 & 50 & 100 & 100 & 25 & 20 \\
\hline Benzamidase & 0 & 0 & 0 & 0 & 0 & 0 & 0 & 0 & 0 & 0 & 89 & 0 & 0 \\
\hline Urease & 97 & 100 & 100 & 100 & 100 & 38 & 20 & 0 & 83 & 100 & 100 & 100 & 40 \\
\hline Nicotinamidase & 94 & 100 & 40 & 82 & 100 & 0 & 100 & 75 & 50 & 100 & 100 & 100 & 0 \\
\hline Pyrazinamidase & 97 & 100 & 40 & 82 & 100 & 0 & 100 & 75 & 50 & 100 & 100 & 100 & 0 \\
\hline Allantoinase & 6 & 69 & 80 & 100 & 0 & 0 & 20 & 0 & 17 & 67 & 22 & 25 & 40 \\
\hline L-Serine as $\mathbf{N}$ and $\mathbf{C}$ sources & 12 & 13 & 0 & 91 & 0 & 0 & 0 & 25 & 0 & 0 & 0 & 0 & 0 \\
\hline $\begin{array}{l}\text { Glucosamine as } \mathrm{N} \text { and } \mathrm{C} \\
\text { sources }\end{array}$ & 18 & 13 & 90 & 91 & 0 & 100 & 20 & 75 & 0 & 0 & 100 & 50 & 0 \\
\hline $\begin{array}{l}\text { Acetamide as } \mathrm{N} \text { and } \mathrm{C} \\
\text { sources }\end{array}$ & 97 & 88 & 20 & 100 & 100 & 0 & 100 & 100 & 0 & 0 & 100 & 0 & 40 \\
\hline $\begin{array}{l}\text { Monoethanolamine as } \mathbf{N} \\
\text { and C sources }\end{array}$ & 6 & 88 & 80 & 100 & 0 & 0 & 80 & 100 & 0 & 0 & 100 & 0 & 60 \\
\hline$n$-Butanol as C source & 33 & 69 & 100 & 91 & 100 & 100 & 100 & 100 & 100 & 0 & 78 & 0 & 20 \\
\hline Isobutanol as $\mathrm{C}$ source & 36 & 69 & 100 & 91 & 100 & 100 & 100 & 100 & 100 & 0 & 78 & 0 & 0 \\
\hline Citrate as $\mathrm{C}$ source & 52 & 81 & 80 & 91 & 100 & 50 & 100 & 100 & 17 & 100 & 22 & 100 & 80 \\
\hline Benzoate as C source & 0 & $\mathbf{0}$ & 60 & 18 & 0 & 63 & 0 & 75 & 0 & 0 & 11 & 0 & 0 \\
\hline Fumarate as $\mathrm{C}$ source & 100 & 88 & 100 & 100 & 67 & 100 & 80 & 100 & 100 & 0 & 100 & 100 & 60 \\
\hline Sucrose as $\mathrm{C}$ source & 100 & 100 & 100 & 100 & 100 & 100 & 80 & 100 & 0 & 67 & 44 & 100 & 100 \\
\hline Ethanol as C source & 58 & 94 & 100 & 91 & 100 & 100 & 100 & 100 & 33 & 0 & 89 & 0 & 80 \\
\hline $\begin{array}{c}\text { Propylene glycol as } \mathrm{C} \\
\text { source }\end{array}$ & 48 & 6 & 60 & 82 & 0 & 100 & 100 & 100 & 17 & 0 & 67 & 0 & 0 \\
\hline Acid from glucose & 100 & 100 & 100 & 100 & 100 & 100 & 100 & 100 & 67 & 0 & 100 & 100 & 100 \\
\hline Acid from mannose & 97 & 100 & 100 & 100 & 100 & 88 & 100 & 0 & 0 & 0 & 67 & 100 & 100 \\
\hline Mannose as C source & 100 & 100 & 100 & 100 & 100 & 100 & 100 & 100 & 0 & 0 & 89 & 100 & 100 \\
\hline Galactose as C source & 3 & 0 & 0 & 91 & 0 & 0 & 0 & 0 & 0 & 0 & 0 & 0 & 0 \\
\hline Rhamnose as C source & 0 & 6 & 30 & 0 & 0 & 0 & 0 & 0 & 0 & 0 & 67 & 0 & 0 \\
\hline Trehalose as C source & 100 & 100 & 100 & 100 & 100 & 0 & 0 & 0 & 0 & 0 & 44 & 100 & 100 \\
\hline Inositol as $\mathrm{C}$ source & 100 & 0 & 0 & 91 & 0 & 0 & $\mathbf{0}$ & 0 & 0 & 0 & 22 & 0 & 0 \\
\hline Mannitol as C source & 42 & 100 & 100 & 100 & 0 & 0 & 100 & 100 & 0 & 33 & 0 & 100 & 100 \\
\hline Sorbitol as C source & 0 & 100 & 100 & 100 & 0 & 0 & 100 & 100 & 0 & 0 & 0 & 100 & 100 \\
\hline Acetamide as $\mathrm{N}$ source & 100 & 100 & 100 & 100 & 100 & 100 & 100 & 100 & 100 & 0 & 100 & 0 & 100 \\
\hline Benzamide as $\mathbf{N}$ source & 0 & 0 & 0 & 0 & 0 & 0 & 40 & 0 & 83 & 0 & 33 & 0 & 0 \\
\hline Urea as $\mathrm{N}$ source & 88 & 56 & 100 & 100 & 100 & 100 & 100 & 100 & 100 & 0 & 100 & 0 & 0 \\
\hline Nicotinamide as $\mathbf{N}$ source & 88 & 88 & 100 & 100 & 100 & 100 & 100 & 100 & 100 & 0 & 100 & 0 & 80 \\
\hline Nitrate as $N$ source & 70 & 100 & 100 & 100 & 100 & 100 & 80 & 100 & 100 & 0 & 100 & 0 & 80 \\
\hline
\end{tabular}

${ }^{a}$ Cluster. (A) Rhodococcus bronchialis (Gordona bronchialis); (B) R. sputi; (C) R. rubropertinctus (G. rubropertincta); (D) R. aurantiacus (G. aurantiaca); (E) R. rhodochrous (G. rhodochroa); (G) Nocardia rubra (Ridell); (H) R. lentifragmentus (G. lentifragmenta); (I) N. asteroides; (K) N. farcinica. E, J, M, and N are unnamed Rhodococcus clusters. The clusters shown in this table are those obtained by method II (98 characters).

${ }^{b}$ Number of strains. 
Gordona sensu stricta and the rhodochrous complex as belonging to the same genus, Rhodococcus, based on the phenetic data presented in our previous studies (15-17) and in the present study. In this case, nomenclature of the Rhodococcus species will be as follows: $R$. rhodochrous Zopf 1891 (21) (synonym: G. rhodochroa Tsukamura 1973 [15]); $R$. bronchialis Tsukamura (synonym: $G$. bronchialis Tsukamura 1971 [14]); $R$. rubropertinctus (Hefferan) comb. nov. Tsukamura (synonym: G. rubropertincta [Hefferan] Tsukamura 1973 [15]; G. rubra Tsukamura 1971 [14]); $R$. aurantiacus Tsukamura and Mizuno (synonym: G. aurantiaca Tsukamura and Mizuno 1971 [19]); $R$. lentifragmentus Tsukamura, Mizuno, and Murata (synonym: G. lentifragmenta Tsukamura, Mizuno, and Murata 1975 [20]); $R$. sputi Tsukamura sp. nov.

In conclusion, the Rhodococcus cluster consisting of Gordona sensu stricta and the rhodochrous complex could be distinguished from the clusters of $N$. asteroides, $N$. farcinica, and $M$. fortuitum. It contained more than several clusters. This finding supports the opinion that the Rhodococcus (synonym: Gordona) taxon is a genus containing a number of species and is distinguished from Nocardia and Mycobacterium.

\section{ACKNOWLEDGMENTS}

The technical assistance of S. Mizuno, H. Murata, and M. Oshima is acknowledged. I thank S. Uchida, the Sumitomo Machinery Co., for his kind help in using the computer.

\section{ADDENDUM}

After preparation of this manuscript, two papers of Goodfellow and Alderson (J. Gen. Microbiol. 100:99-122, 1977) and Rowbotham and Cross (J. Gen. Microbiol. 100:123-138, 1977) appeared. These authors also concluded that both the rhodochrous taxon and Gordona taxon should be combined into one genus, Rhodococcus. Their proposals agree with the opinion expressed in the present paper.

\section{REPRINT REQUESTS}

Address reprint request to: Dr. M. Tsukamura, the National Chubu Hospital, Obu, Aichi, Japan 474.

\section{LITERATURE CITED}

1. Alshamaony, L., M. Goodfellow, D. E. Minnikin, and H. Mordarska. 1976. Free mycolic acids as criteria in the classification of Gordona and the 'rhodochrous' complex. J. Gen. Microbiol. 92:183-187.

2. Bousfield, I. J., and M. Goodfellow. 1976. The "rhodochrous" complex and its relationships with allied taxa, p. 39-65. In M. Goodfellow, G. H. Brownell, and J. A. Serrano (ed.) The biology of the Nocardiae. Academic Press Inc., New York.
3. Bradley, S. G. 1971. Criteria for definition of Mycobacterium, Nocardia and the rhodochrous complex. Adv. Front. Plant Sci. 28:349-362.

4. Goodfellow, M. 1971. Numerical taxonomy of some nocardioform bacteria. J. Gen. Microbiol. 69:33-80.

5. Goodfellow, M., A. Fleming, and M. J. Sackin. 1972. Numerical classification of "Mycobacterium" rhodochrous and Runyon's group IV mycobacteria. Int. J. Syst. Bacteriol. 22:81-98.

6. Goodfellow, M., A. Lind, H. Mordarska, S. Pattyn, and M. Tsukamura. 1974. A co-operative numerical analysis of cultures considered to belong to the 'rhodochrous' taxon. J. Gen. Microbiol. 85:291-302.

7. Gordon, R. E. 1966. Some strains in search of a genus-Corynebacterium, Mycobacterium, Nocardia or what? J. Gen. Microbiol. 43:329-343.

8. Gordon, R. E., and J. M. Mihm. 1957. A comparative study of some strains received as nocardiae. J. Bacteriol. 73:15-27.

9. Mordarski, M., K. Szyba, G. Pulverer, and M. Goodfellow. 1976. Deoxyribonucleic acid reassociation in the classification of the 'rhodochrous' complex and allied taxa. J. Gen. Microbiol. 94:235-245.

10. Ridell, M. 1974. Serological study of nocardiae and mycobacteria by using "Mycobacterium" pellegrino and Nocardia corallina precipitation reference systems. Int. J. Syst. Bacteriol. 24:64-72.

11. Sokal, R. R., and P. H. A. Sneath. 1963. Principles of numerical taxonomy, p. 1-359. W. H. Freeman, San Francisco.

12. Tsukamura, M. 1967. Identification of mycobacteria. Tubercle 48:311-338.

13. Tsukamura, M. 1969 . Numerical taxonomy of the genus Nocardia. J. Gen. Microbiol. 56:265-287.

14. Tsukamura, M. 1971. Proposal of a new genus, Gordona, for slightly acid-fast organisms occurring in sputa of patients with pulmonary disease and in soil. J. Gen. Microbiol. 68:15-26.

15. Tsukamura, M. 1973. A taxonomic study of strains received as "Mycobacterium" rhodochrous. Description of Gordona rhodochroa (Zopf; Overbeck; Gordon et Mihm) Tsukamura comb. nov. Jpn. J. Microbiol. 17:189-197.

16. Tsukamura, M. 1974. A further numerical taxonomic study of the Rhodochrous group. Jpn. J. Microbiol. 18:37-44.

17. Tsukamura, M. 1975. Numerical analysis of the relationship between Mycobacterium, rhodochrous group, and Nocardia by use of hypothetical median organisms. Int. J. Syst. Bacteriol. 25:329-335.

18. Tsukamura, M. 1976. Numerical classification of slowly growing mycobacteria. Int. J. Syst. Bacteriol. 26:409-420.

19. Tsukamura, M., and S. Mizuno. 1971. A new species Gordona aurantiaca occurring in sputa of patients with pulmonary disease. Kekkaku 46:93-98.

20. Tsukamura, M., S. Mizuno, and H. Murata. 1975. Numerical taxonomy study of the taxonomic position of Nocardia rubra reclassified as Gordona lentifragmenta Tsukamura nom. nov. Int. J. Syst. Bacteriol. 25:377-382.

21. Zopf, W. 1891. Ueber Ausscheidung von Fettfarbstoffen (Lipochromen) seitens giwisser Spaltpilze. Ber. Dtsch. Bot. Ges. 9:22-28. Cited in R. E. Buchanan, J. G. Holt, and E. F. Lessel, Jr. (ed.). 1966. Index Bergeyana. The Williams \& Wilkins Co., Baltimore. 